\title{
Oceans and Space: New Frontiers in Investment Protection? \\ An Introduction
}

\author{
Stephan W. Schill \\ University of Amsterdam, The Netherlands \\ s.w.b.schill@uva.nl \\ Christian J. Tams \\ University of Glasgow, United Kingdom \\ Christian.Tams@glasgow.ac.uk \\ Rainer Hofmann \\ Goethe University, Frankfurt am Main, Germany \\ R.Hofmann@jur.uni-frankfurt.de
}

\begin{abstract}
This article provides background and introduces into the overarching themes of the contributions to the Special Issue dealing with investment protection in areas beyond territorial jurisdiction at sea and in outer space. It explains that fast-paced commercialization, evolving technological advances, and the inevitable need for regulatory intervention make the oceans and space into an increasingly important topic in international investment law. At the same time, investment lawyers, as well as experts in the law of the sea and space law, have largely ignored the legal issues foreign investments raise in these spaces. The article sketches out a framework for addressing the underlying issues from an investment law perspective, pointing out both familiar conceptual approaches and novel challenges.
\end{abstract}

* The articles forming part of this Special Issue were first presented, on 10 and 11 March 2017, at the Frankfurt Investment Law Workshop, an annual event focusing on the discussion of conceptual and foundational issues of international investment law. Publications of past workshops include Rainer Hofmann and Christian J Tams (eds), The International Convention on the Settlement of Investment Disputes (ICSID): Taking Stock after 40 Years (Nomos 2007); Rainer Hofmann and Christian J Tams (eds), International Investment Law and General International Law (Nomos 2011); Rainer Hofmann and Christian J Tams (eds), Investment

(C) SCHILL, TAMS AND HOFMANN, 2018 DOI:10.1163/22119000-12340119

This is an open access article distributed under the terms of the prevailing CC-BY-NC license at the time of publication. 


\section{Keywords}

foreign investment - political risk - oceans - space - international investment treaties - territory - law of the sea - space law

International investment law is widely seen as an avant-garde field of international law, which breaks with tradition: it is (still) a relatively young discipline that has experienced fast growth, to begin with; unlike in other areas, nonState actors play a major role in it, perhaps 'greater than in any other area;'1 and binding dispute settlement (elsewhere no more than an aspiration) is common. Yet, for all its (real or perceived) novelty, international investment law is deeply traditional in another respect. In order to enjoy protection, investments have to be connected to a host State, and the required nexus is a territorial one: ubiquitous definitional provisions operationalise it, almost inevitably requiring (explicitly or implicitly) investments to have been made in the territory of the host State. Looked at from this perspective, the avant-garde field is safely grounded: it is tied to one of international law's cardinal notions, and embedded in 'the bounded territories of the international state system.'

All this made eminent sense as an ordering paradigm for traditional investment flows between State territories. Archetypal direct investment projects whether factories for the production of goods, companies for the provision of services, or infrastructure projects for the production of energy - tended to have a physical presence and clear territorial foothold on foreign soil. Expanded notions of investment and increasingly diversified investment

Law and Its Others (Nomos 2012); Rainer Hofmann, Stephan W Schill and Christian J Tams (eds), Preferential Trade and Investment Agreements: From Recalibration to Reintegration (Nomos 2013); Stephan W Schill, Christian J Tams and Rainer Hofmann (eds), International Investment Law and Development; Bridging the Gap (Edward Elgar 2015); Christian J Tams, Stephan W Schill and Rainer Hofmann (eds), International Investment Law and the Global Financial Architecture (Edward Elgar 2017); Stephan W Schill, Christian J Tams and Rainer Hofmann (eds), International Investment Law and History (Edward Elgar 2018).

Stephan W Schill would like to acknowledge support in preparing this Special Issue by a European Research Council Starting Grant on 'Transnational Private-Public Arbitration as Global Regulatory Governance: Charting and Codifying the Lex Mercatoria Publica' (LexMercPub - Grant Agreement No 313355) carried out at the Amsterdam Center for International Law (ACIL) of the University of Amsterdam.

1 Patrick Dumberry and Erik Labelle-Eastaugh, 'Non-State Actors in International Investment Law' in Jean d'Aspremont (ed), Participants in the International Legal System: Multiple Perspectives on Non-State Actors in International Law (Routledge 2011) 360.

2 See Carl Landauer, 'The Ever-Ending Geography of International Law: The Changing Nature of the International System and the Challenge to International Law' (2014) 25(1) EJIL 31-34. 
activities put some stress on the system, as reflected in debates about financial services, portfolio investment and the turn to a "functional" interpretation of the territorial nexus. ${ }^{3}$ However, all this could and can be accommodated within a system focused on State territory: the nexus is construed more tenuously, but not given up.

The 'new frontiers' addressed in this Special Issue pose challenges of a different nature. They look at investment activities beyond the traditional territorial nexus, and proceed from a simple proposition: spaces beyond territorial sovereignty - at sea and in outer space - are increasingly important sites of private commercial activities. Some such spaces of course have been important for centuries. Debates about the proper regime of navigation and fisheries in the high seas have driven the development of modern international law. In the course of the 2oth century, oceans have become crucial sites of energy production, most importantly as regards the exploration and exploitation of oil and gas. The more recent move towards renewables - think of offshore windfarms or ocean power plants - corroborates this trend. Similarly, submarine cables and pipelines are vital means of connecting societies and economies - and can cause political controversies, as the construction of the Nord Stream 2 pipeline across the Baltic Sea shows. Finally, deep seabed mining, long viewed as the potential next 'gold rush', seems eventually to become economically viable.

What is true for the oceans, seems to come true for outer space. The satellite communications sector has seen significant growth. Space mining and spacefaring are being discussed seriously; space tourism is touted as a potential new business; and States prepare national laws with a view to regulating (and reaping the benefits of) these new opportunities. Most importantly, as space, once more, appears as a 'new frontier', the space industry is undergoing a fundamental shift: States and State-owned entities are gradually replaced by the private sector whose potential for innovation and investment is coveted, harnessed, and feared.

3 Alessandra Arcuri and Federica Violi, 'Reconfiguring Territoriality in International Economic Law' (2016) 47 NYBIL 175, 202. The authors notably cite the majority view in Abaclat and others $v$ Argentina, ICSID Case No ARB/07/5, Decision on Jurisdiction and Admissibility (4 August 2011) para 374, which considered that 'with regard to an investment of a purely financial nature, the relevant criteria cannot be the same as those applying to an investment consisting of business operations and/or involving manpower and property. ... the relevant criteria should be where and/or for the benefit of whom the funds are ultimately used, and not the place where the funds were paid out or transferred. Thus, the relevant question is where [sic] the invested funds ultimately made available to the Host State and did they support the latter's economic development.' 
And yet, questions concerning investment in oceans and space are largely ignored in international law scholarship. While the commercialization of the oceans and space is well known to law of the sea and space law experts, they hardly ever addressed these phenomena with a focus on the specific investment matters at stake. Investment lawyers (who would likely adopt an investment perspective), in turn, have so far largely overlooked the oceans and space altogether. And yet, both groups ignore these 'new frontiers in investment protection' at their peril. The activities just sketched out - from oil exploration to space mining - certainly bear similarities to traditional forms of investment: they depend on the commitment of significant sums of private capital towards projects in areas controlled and regulated by governments, and require upfront investment that will only be recuperated after prolonged periods of time.

What is more, investment in areas beyond territorial sovereignty has to cope with fast-evolving technologies, changing risks and considerable legal uncertainty - challenges that go to the heart of international investment law's purpose, that is, to help control and mitigate political risk. And in fact, while disputes between foreign investors and States relating to investments in space or at sea are still very rare, there are first signs of change on the horizon, illustrated by cases, such as CC/Devas $v$ India, ${ }^{4}$ Deutsche Telekom $v$ India,${ }^{5}$ and Eutelsat $v$ Mexico $^{6}$ (all concerning investments in the satellite industry), or Rockhopper $v$ Italy $^{7}$ (dealing with offshore oil and gas exploration).

Even though the commercialization of spaces beyond territorial sovereignty is in many ways peculiar, it does raise fundamental questions that are central for investment protection irrespective of the localisation of the investment. How are the activities of commercial actors operating on the oceans or in space protected against political risk? Which States can political risk originate from? What law, if any, protects investors? Is that law effective? How do different sources of law, such as international law, national legislation, and contracts between States and investors interrelate? How do the different branches of international law involved interact? How does the applicable law balance commercial interests against regulatory concerns, including the protection

4 CC/Devas (Mauritius) Ltd, Devas Employees Mauritius Private Limited, and Telcom Devas Mauritius Limited $v$ Republic of India, PCA Case No 2013-09, Award on Jurisdiction and Merits (25 July 2016).

5 Deutsche Telekom AG v Republic of India, PCA Case No 2014-10, Interim Award (13 December 2017).

6 See Zoe Williams, 'Mexico Faces New Investor-State Arbitration Brought by French Satellite Company' (IAReporter, 17 August 2017).

7 See 'Italy's Ban on Oil and Gas Development Near Its Coastline Leads to Investment Treaty Arbitration Claim' (IAReporter, 23 March 2017). 
of the environment, national security concerns, and the concept of common heritage of mankind, which plays a role both in outer space and the law of the sea? And how can disputes that will necessarily arise be settled in an efficient and balanced manner?

These issues have so far hardly been explored systematically, neither by investment lawyers, nor by specialists in the law of the sea or international space law. The contributions to the present Special Issue are a first attempt at charting how international investment law interacts with the law of the sea and international space law and how political risk is mitigated in spaces beyond territorial sovereignty. They investigate the traditional sources of investment protection, such as investment treaties, contractual arrangements, and national legislation, and shed light on how they apply to investments at sea and in space.

The Special Issue opens with an article by Christopher Greenwood. In it, he lays the foundations for the three larger sets of questions that are central when looking at the protection of foreign investment at sea and in space: first, whether international investment law, the law of the sea, and space law interact cooperatively or show signs of fragmentation; second, whether investment treaties apply to areas beyond territorial jurisdiction; and third, to which extent public interests and investment protection are balanced in case of regulatory action. The theme arising from Greenwood's analysis is that the tools and instruments developed to address interactions between investment law and other fields of international law also apply when looking at the law of the sea and international space law.

The following set of articles turn to investments at sea. Seline Trevisanut and Nikolaos Giannopoulos delve into the regulation of offshore energy projects and untangle the multitude of overlapping international legal regimes governing them. Instead of emphasizing resulting friction, they show how regime interaction can contribute to widening the objectives of international investment law, arguing, inter alia, that the approach of the United Nations Convention on the Law of the Sea (UNCLOS) to granting different levels of sovereign rights in different maritime zones should help make the case to extend the territorial scope of application of investment treaties to such zones. Furthermore, they argue that regime interaction in offshore energy projects should have the effect that foreign investors themselves will have an incentive to ensure that States comply with their UNCLOS obligations in order not to endanger the success of a foreign investment project at sea. 
Peter Tzeng then turns to the highly important and legally unsettled issue of how political risk can be managed in respect of foreign investment projects in disputed maritime areas, that is, areas where more than one State claims to exercise sovereign rights. This encompasses unregulated areas, joint development areas, and provisionally delimited areas. Tzeng shows that investment treaties and the dispute settlement options they offer are just one instrument to manage political risk, which faces, depending on the circumstances, a number of potential limitations, including the question of whether investment tribunals are empowered to make determinations on the underlying sovereignty dispute. Consequently, as Tzeng shows, investor-State contracts or political risk insurance may proof to be the instruments of choice in offering investment protection in contested maritime zones.

Submarine cables and pipelines are the topic addressed by Markos Karavias. His article sheds light on the question whether investment treaties apply to investments in maritime cables and pipelines. Distinguishing between different models used to implement such operations, and different maritime zones cables and pipelines may cross, his main focus is on the territorial nexus investment treaties generally require to apply to a concrete investment. The most vexed question, in this respect, concerns those parts of a cable or pipelines that is located in the seabed and therefore outside the zones where States exercise sovereign rights. The difficulties relating to the territorial application of investment treaties notwithstanding, Karavias points out that investment disputes relating to cables and pipelines are rare, one of the reasons being that political risk is regularly successfully minimized already when the cables' or pipelines' routes are planned.

Joanna Dingwall, in the last contribution on the law of the sea, looks at deep seabed mining, a commercial activity that is becoming increasingly important in light of mineral resources, including valuable metals and rare earth elements, in the 'Area', the UNCLOS terminology for 'the seabed and ocean floor and subsoil thereof, beyond the limits of national jurisdiction' (UNCLOS, art 1(1)). States, however, are not the principal actors in regulating deep seabed mining. Instead, the International Seabed Authority takes up this role in regulating the Area and granting mining contracts to investors. The Authority is therefore also Dingwall's primary focus as a source of political risk. In her article, she shows that while investment treaties play only a negligible role for deep seabed mining, the UNCLOS regime itself provides for investment protection that is in substance comparable to that under international investment law.

The second part of this Special deals with the mitigation of political risk in space-related commercial ventures. Ingo Baumann, Hussaine El Bajjati, and 
Erik Pellander open this part with introducing into the main differences between the traditional space industry, which was dominated by public actors, and what they call 'NewSpace', that is, the present-day structure of economic activities in outer space. NewSpace is characterized not only by new technologies, in particular in the information and communications sector, but above all by significant amounts of private investments, making commercial space activities into a multi-billion dollar industry. The rapid developments in this sector, in turn, raise, as the authors show, a host of new regulatory issues and political risks, in manufacturing space products, launching space objects, rendering satellite services, and operating ground equipment. Investment treaties, in the authors' view, could help to mitigate some of the involved risks, provided a sufficient territorial nexus can be found to a host State.

Peter Malanczuk then analyzes the traditional legal framework governing outer space, which consists of an amalgam of international treaties (including the Outer Space Treaty, the Moon Agreement, the Liability Convention, and the Registration Convention), and national space legislation. He argues that this framework, to a large extent, fails to address the needs of private space enterprises in providing stability and predictability. Problems encompass the level of divergence of national space laws, the lack of agreement on the delimitation between air space and outer space, and the lack of international regimes for a variety of space activities, including safety and navigation of aerospace vehicles, space debris, and property rules on space resources. Investment treaties, as Malanczuk shows, will only help mitigate political risk in outer space to a limited extent, not only because of limitations in their territorial scope of application, but also because of the specific national security concerns regularly involved. At present, investment contracts, licenses, political risk insurance, and arbitration agreements, may therefore be the best instruments to mitigate political risk in outer space.

Mahulena Hofmann and P.J. Blount in their article focus on the newly emerging sector of space mining and the legal framework governing it. Apart from public international law, space mining is addressed in newly passed domestic legislation, as the case of the United States and Luxembourg illustrate. New laws of these two countries regulate space resource activities and aim at providing predictability in respect of the property regime applying to space resources exploited through mining. Initially, concerns as to whether these domestic legislations were in conformity with international space law, in particular the prohibition of appropriation of celestial bodies, were prominent. Meanwhile, the situation gradually changes towards a more constructive discussion on the future international regime to govern the exploitation of space resources. In order to ensure legal certainty for the operators of, and investors 
in, space mining resource activities, such a regime, Hofmann and Blount argue, should include an international registry of the respective rights and an international institution capable of administering it.

The Special Issue closes with an article by Stephan Hobe, Rada Popova, Hussaine El Bajjati, and Julian Scheu who address the protection of satellite telecommunications activities under bilateral investment treaties (BITs). Distinguishing between the pre-launch phase, the launching phase, the onorbit phase, and the end-of-lifetime phase, they show that investment treaties can come into play to mitigate political risk in respect of all of these phases. The tricky question, however, will be to determine which State is the host State, as it is not uncommon that several States are involved in the launch and operation of a satellite. Investment treaties, the authors argue, can be interpreted in a way that investors in satellite activities receive broad protection against different aspects of political risk, including against the refusal to issue necessary licenses, conduct a promised launch, protect the launch site physically, refrain from action that may harm a satellite's operation on orbit, and respect commitments made in relation to frequencies used by a satellite.

The articles in this Special Issue do not provide a comprehensive conceptualization of the interaction between investment law, the law of the sea, and international space law, nor do they address all problems that investment projects at sea or in space face. Still, the contributions provide a solid basis for charting so far little-mapped territory. While many questions concerning foreign investment at sea and in outer space will arise only once technology, economics, environmental and social impact assessment, and regulatory responses have further advanced, the contributions to this Special offer a framework and a compass: a framework in which challenges are presented in terms familiar to investment lawyers, and a compass that can guide future inquiries.

While 'new frontiers' are daunting, the contributions also yield a number of comforting conclusions. First, they show that many of the challenges facing investments at sea and in space are familiar to investment lawyers, and in fact public international lawyers more generally. Challenges presented by the interaction with public authorities, be they States or international administrations (such as the International Seabed Authority), can be rationalized in terms of political risk. As with traditional cross-border investments, their resolution will depend on a balancing of competing interests: the need for stability of the governing legal framework and predictability of the regulatory action, 
on the one hand, and the need to protect competing public interests, including public health, the protection of the environment, and security, on the other. Similarly, the interaction between international investment law and the law of the sea or international space law can be conceptualized and put in practice in ways that are familiar from international law's previous encounters with 'its others': through cooperation, rather than in an antagonistic manner.

Second, the instruments that come into play to mitigate political risk and to balance investor interests and competing concerns are those familiar from many other field of investment activity. Thus, despite the novel spatial dimensions of foreign investments at sea and in space, most of the classical instruments of investment protection will play a role in managing political risk. Thus, international investment treaties will in many cases apply and provide substantive protections as well as procedural recourse to foreign investors affected by State measures. Where investment treaties do not apply, for example because of specific national security carve-outs or because the investment in question simply cannot be made to fit a territorial nexus, however tenuous, other equally classical instruments to mitigate political risk will come in, whether investor-State contracts, concessions and licenses, or political risk insurance. In this respect, investment protection at sea or in space may resemble the protection of foreign investment in the pre-BIT era.

These traditional fixpoints notwithstanding, the regulation of foreign investment at sea and in space and its protection against undue interference by public authorities will remain a continuous challenge. The contributions to this Special Issue show, for example, that private investment activities may need to receive more attention in the public international law frameworks governing outer space, and to a lesser degree the law of the sea. In space, in particular, many regulatory gaps remain, which would ideally be closed through multilateral frameworks, e.g. in respect of space mining or space debris. National legislation may close this gap temporarily, but in the long run will certainly raise its own questions of political risk assessment. What if, for example, national legislation that permits and regulates space mining, or some other space activity, turns out to contravene existing public international law frameworks? Will the States authoring such legislation (have to) live up to expectations of investors created by such legislation, or do investors bear the risk that such legislation is contrary to public international law? Similarly, in respect of some investment activities at sea, such as deep seabed mining, where States are not the principal source of political risk and where investment treaties will not apply, the existing UNCLOS framework may need to be complemented to provide for adequate levels of investment protection, while ensuring that competing public interests are not undermined. 
Future regulation and re-regulation of economic activities at sea and in space can be expected to pose continuing challenges as technology and knowledge about the social, economic, and environmental impact of certain economic activities progress. What may be permitted and little-regulated today, may tomorrow require tighter regulation (or even be forbidden completely) in order to protect competing interests. It does not take much imagination to expect that future re-regulation will be challenged by investors whose economic expectations are disappointed. With increasing commercialization of the sea and outer space and the development of new technologies, disputes about the limits of legitimate regulation and re-regulation and controversies about the scope of duties of commercial actors in the respective ventures will arise and demand solutions.

To provide such solutions, the traditional frameworks for analyzing political risk under international investment law, familiar from other contexts, will likely provide pointers and precedents. But more likely than not, we will have to leave the comfortable structures of present-day investment law and develop new forms of mitigating political risk, and new methods of balancing economic and non-economic interests in the use of spaces beyond national sovereignty. While the existing structures should not be discarded, the 'new frontiers of investment protection' are likely to require new intellectual and legal frameworks. In mapping out these new frameworks, we would benefit from some of the pioneering spirit that drove seafarers, such as Christopher Columbus, Zheng He, Ferdinand Magellan or James Cook, or the Juri Gagarins, Neil Armstrongs, Anousheh Ansaris and Kalpana Chawlas of 2oth century space adventures. 